\title{
УДК 637.52:664.38
}

INVESTIGATION OF FUNCTIONAL AND TECHNOLOGICAL PROPERTIES OF MINCED MEAT FOR SAUSAGES OF CHICKEN WITH ADDITION OF CHEESE

\author{
ДОСЛІДЖЕННЯ ФУНКЦІОНАЛЬНО-ТЕХНОЛОГІЧНИХ ВЛАСТИВОСТЕЙ \\ ФАРШУ ДЛЯ СОСИСОК КУРИНИХ 3 ДОДАВАННЯМ СИРУ
}

Tyshchenko L.M. / Тищенко Л.М. c.t.s., as.prof. / к.m.н., доu. ORCID: 0000-0002-3609-0920

Krasniuk V.S. / Краснюк B.C.

Master / мazicmp

Національний університет біоресурсів і природокористування України,

Київ, вул. Героїв Оборони 15, 03041

National University of Life and Environmental Sciences of Ukraine,

Kyiv, street Heroiv Oborony 15, 03041

Анотація. В роботі обтрунтована можливість заміни певної частки м'ясної сировини на молочну сировину при виробниџтві сосисок. Було проаналізовано результати впливу внесеного твердого сиру на структурно-механічні властивості фаршів та готових куриних сосисок.

Ключові слова: фарш, м'ясо курки, сосиски, молочна сировина, структурно-механічні властивості.

Вступ. На сьогодні існує потреба у високоякісних і безпечних ковбасних виробах, які відповідають до вимог ДСТУ 4436:2005 "Ковбаси варені, сосиски, сардельки, хліби м'ясні. Загальні технічні умови" [1], які чітко регламентують норми тваринної сировини в складі продукту залежно від сорту. Саме тому збагачення ковбасних виробів рослинною сировиною можливе за рахунок часткової заміни м'ясної сировини.

Структурно-механічні (реологічні) властивості харчових продуктів характеризують їх опірність впливу зовнішньої енергії, обумовлену будовою i структурою продукту, а також якість харчових продуктів, враховуються при виборі умов їх перевезення і зберігання. Реологічні властивості характеризують поведінку продуктів в умовах напруженого стану [2].

Метою досліджень $є$ створення та аналіз м'ясних фаршевих систем iз частковою заміною основної сировини на тверді сири.

Матеріали і методи дослідження: для виконання досліджень були використані стандартні методи визначення структурно-механічних властивостей фаршевих систем та готового продукту: вологозв“язуюча, вологоутримуюча та жироутримуюча здатності, гранична напруга зсуву фаршевих систем.

Експеримент включав 6 досліджуваних зразків з різною кількістю добавки: контрольний зразок - 0 \%; дослід 1 - 5 \% сиру Російського; дослід 2 - 10\% сиру Російського; дослід 3 - 15\% сиру Російського; дослід 4 - 5\% сиру Гауда; дослід 5 - 10\% сиру Моццарела.

Результати досліджень. Для оцінки можливості застосування твердого сиру та визначення оптимальної кількості добавки при виробництві сосисок 
проведено дослідження властивостей сиру, які зводилися до оцінки поводження твердого сиру в багатокомпонентній системі, бо саме від цих властивостей фаршу залежить склад, структура продукту і умови виробництва, зберігання й вживання розробленого продукту. Такі показники, як вологозв'язуюча здатність (В33), вологоутримуюча здатність (ВУЗ) та жироутримуюча здатність (ЖУЗ) дослідного фаршу, безперечно, впливають на соковитість виробів, якість готової продукції та її вихід, величину втрат при тепловій обробці [3].

В якості об'єкта дослідження є модельні фарші із заміною від 5 до 15\% м'яса куриного твердим сиром. Підготовлений фарш перемішували до рівномірного розподілу сиру по всій масі й і наповнли оболонки. Як контроль використовували фарш ковбаси вищого сорту.

Вологозв'язуюча здатність м'ясних продуктів забезпечується перед усім вмістом білків, які є структурними і функціональними елементами м'язової тканини і мають властивості поверхнево-активних речовин. У м'ясних системах білки беруть участь в утворенні водної матриці фаршу і емульгуванні жиру [4].

Результати дослідження вологозв’язуючої здатності фаршів, представлені на рисунку 1, свідчать про те, що введення до складу фаршів сосисок добавок у вигляді твердого сиру, крім збільшенням вмісту білка, сприяє підвищенню його вологозв'язуючої здатності. Так, вологозв'язуюча здатність фаршу сосисок зростає із збільшенням відсотку внесеної добавки.

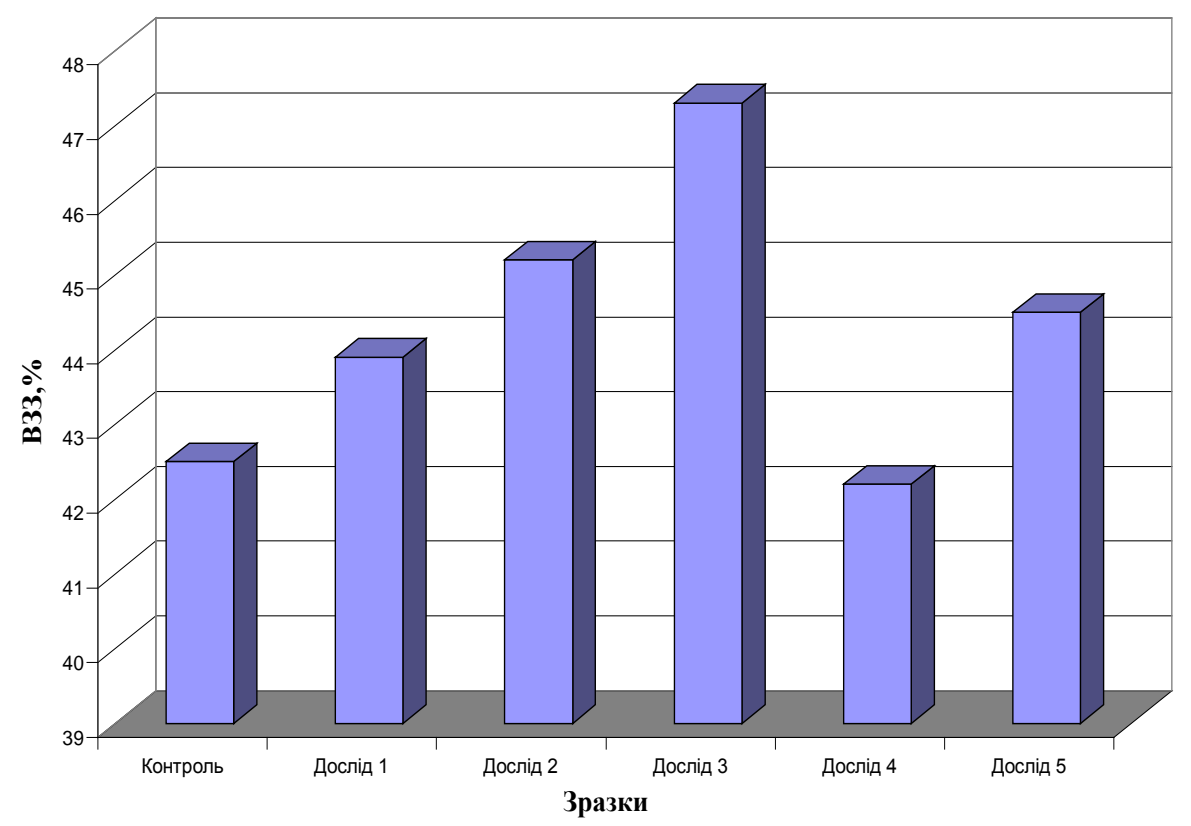

Рисунок 1. Зміни вологозв’язуючої здатності фаршу сосисок 3 додаванням сиру

Вологоутримуюча здатність фаршу майже не змінюється при додаванні до складу м'ясного фаршу сиру при різних концентраціях та при різних видах сиру (рис.2). Якість ковбасних виробів визначається не тільки оптимальною здатністю до вологоутримання, але й жироуримуючою здатністю, що характеризує технологічну стійкість ковбасного виробу при тепловій обробці. 


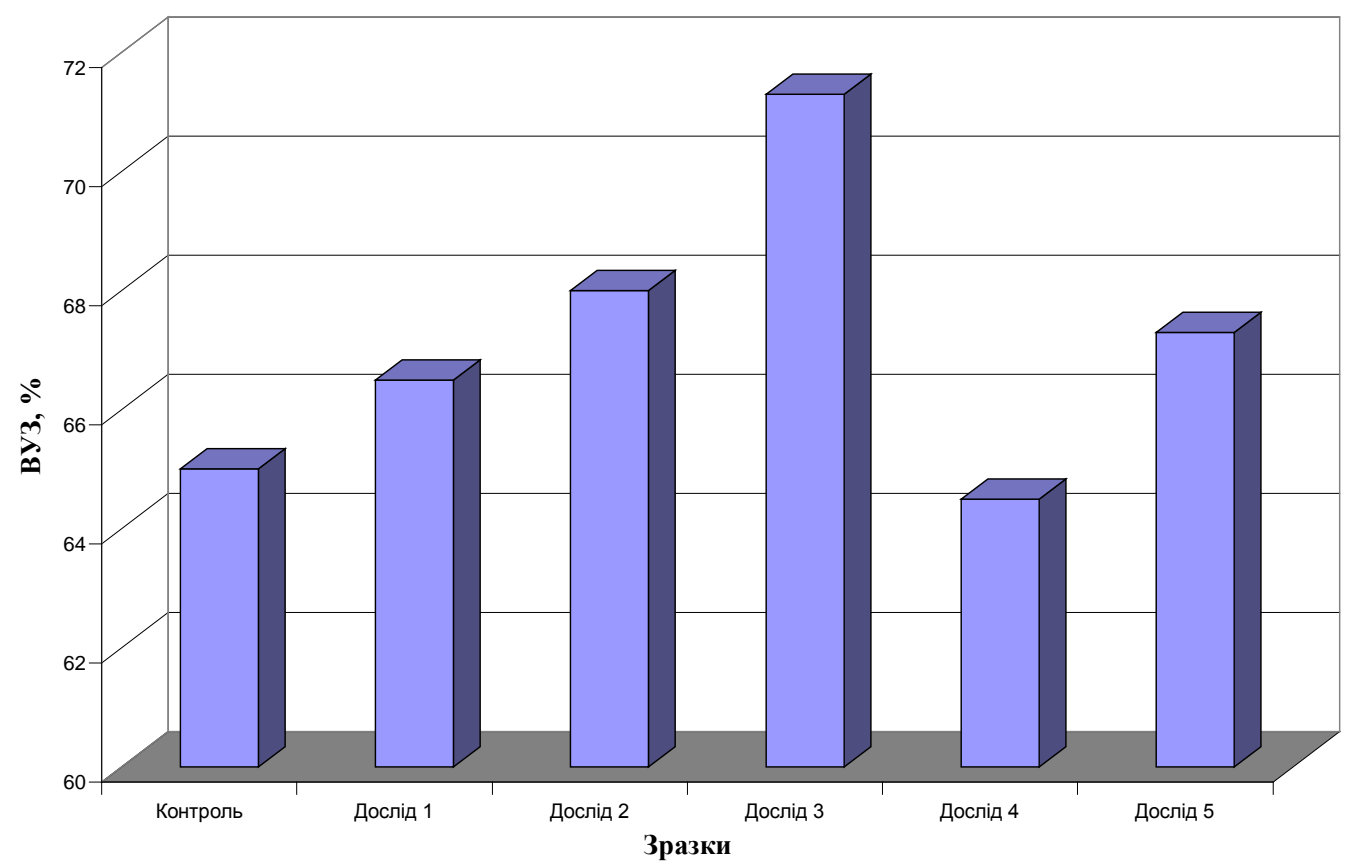

\section{Рисунок 2. Зміни вологоутримуючої здатності фаршу сосисок 3 додаванням сиру}

Результати дослідження жироутримуючої здатності, наведені на рисунку 3 , свідчать, що ЖУЗ фаршу не значно зростає при додаванні твердого сиру. На графіку максимум жироуримуючої здатності фіксується при заміні 15\% курячого м'яса на Російський сир.

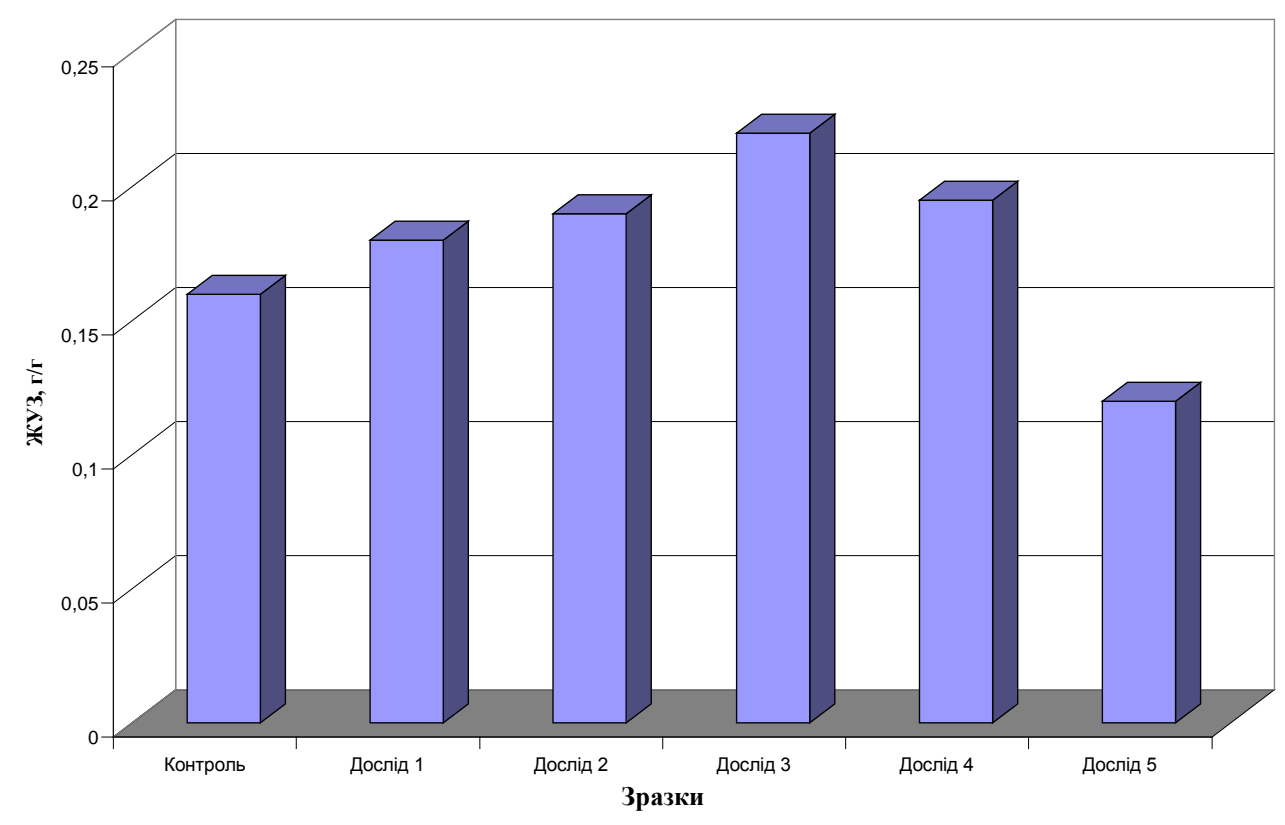

Рисунок 3. Зміни жироутримуючої здатності фаршу сосисок 3 додаванням сиру

Збільшення показників ВУЗ та ЖУЗ пов'язане із збільшенням вільної вологи та неемульгованого жиру у модельних фаршевих системах і, відповідно, зменшенням зв'язаної вологи та емульгованого жиру. 
На рисунку 4 представлено вплив додавання твердого сиру на граничну напругу зсуву фаршів систем сосисок.

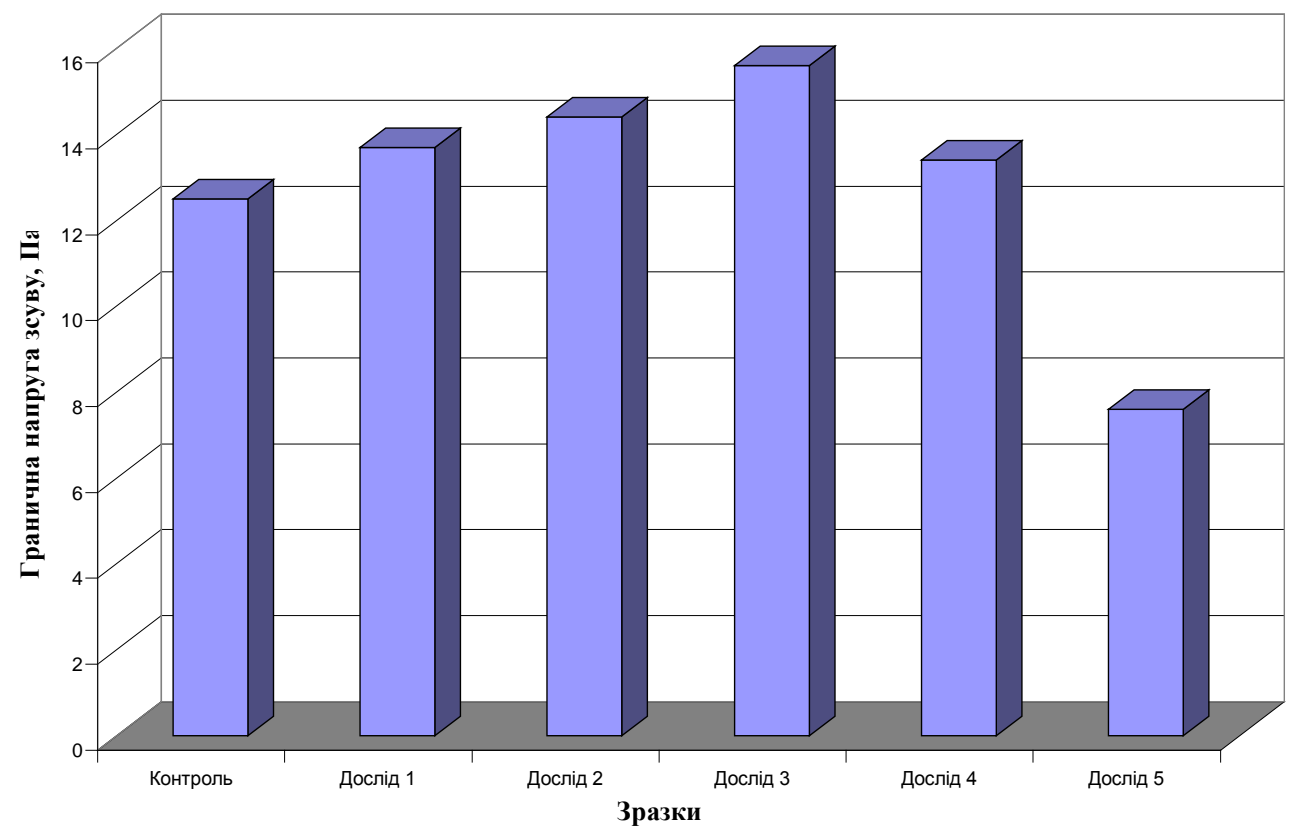

Рисунок 4. Зміна граничного напруження зсуву фаршу сосисок

Аналізуючи дані графіку, можна відмітити, що структурно-механічні властивості у контрольному зразку фаршу нижче, ніж у дослідних зразках. Це свідчить про меншу пружність та міцність і відповідає більшому вмісту вологи. Фарш із додаванням сиру має більш ніжну та соковиту консистенцію.

\section{Висновок.}

Аналіз впливу молочної добавки на функціонально-технологічні властивості фаршу для сосисок показав, що заміна у рецептурі сосисок $10 \%$ курячого м'яса на Російський сир призводить до помітного покращення консистенції фаршу. Таким чином, використання у складі курячих сосисок твердого сиру в запропонованому оптимальному співвідношенні забезпечує отримання стабільних якісних характеристик сосисок.

\section{Література.}

1. ДСТУ 4436:2005 "Ковбаси варені, сосиски, сардельки, хліби м'ясні. Загальні технічні умови"

2. Структурно-механические характеристики пищевых продуктов / Горбатов А.В., Маслов А.М., Мачихин Ю.А. и др.- М.: Лёгкая и пищевая промышленность, 1982. -296 с.

3. Физико-химический и бактериологический контроль в мясной промышленности / М.Б. Коган, Л.С. Пожарская, В.П. Рындина, Е.М. Фрейдлин/ Справочное руководство, 2-е изд. - М.: Пищевая промышленность, 1971. -462 c.

4. Антипова Л. В., Глотова И. А., Рогов И. А. Методы исследования мяса и мясных продуктов. - М.: Колос,2001. -376 с. 


\section{References:} umovy"

1. DSTU 4436:2005 "Kovbasy vareni, sosysky, sardelky, khliby miasni. Zahalni tekhnichni

2. Strukturno-mekhanycheskye kharakterystyky pyshchevykh produktov / Horbatov A.V., Maslov A.M., Machykhyn Yu.A. y dr.- M.: Lëhkaia y pyshchevaia prombshlennost,1982. -296 s.

3. Fyzyko-khymycheskyi y bakteryolohycheskyi kontrol v miasnoi promyshlennosty / M.B. Kohan, L.S. Pozharskaia, V.P. Rundyna, E.M. Freidlyn/ Spravochnoe rukovodstvo, 2-e yzd. - M.: Pyshchevaia promyshlennost, 1971. -462 s.

4. Antypova L. V., Hlotova Y. A., Rohov Y. A. Metody issledovanyia miasa i miasnykh produktov. - M.: Kolos,2001. -376 s.

Abstract. In the work on the basis of literary sources, the possibility of replacing a certain proportion of meat raw material with dairy raw material in the production of sausages was substantiated. The results of the influence of the introduced hard cheese on the structural and mechanical properties of minced meat and prepared chicken sausages were analyzed.

Keywords: minced meat, chicken meat, sausages, dairy raw materials, structural and mechanical properties.

Науковий керівник: к.т.н., доцент Тищенко Л.М. Стаття відправлена 7.11.2018 р. (СТищенко Л.М. 